\title{
Epidermolysis bullosa simplex superficialis
}

INSERM

\section{Source}

INSERM. (1999). Orphanet: an online rare disease and orphan drug data base.

Epidermolysis bullosa simplex superficialis. ORPHA:89839

Epidermolysis bullosa simplex superficialis (EBSS) is a suprabasal subtype of

epidermolysis bullosa simplex (EBS, see this term) characterized by generalized or acral superficial erosions in the absence of blisters. 